\title{
Academic Digital Libraries of the Future: An Environment Scan
}

\section{Introduction}

Hermann Hesse's following famous quotation has defined the world which libraries have inhabited for several centuries:

Without words, without writing and without books there would be no history, there could be no concept of humanity.

But it is no longer absolutely clear whether this view of the world is a vibrant legacy or whether it is a set of chains holding us back. The inexorable march of digital content and images should give pause as to what now constitutes that concept of humanity. In recent years literally dozens of reports have been published on various aspects of information futures. It is almost impossible to list them comprehensively, far less to keep abreast of them all and synthesize their conclusions and recommendations. Given this, any environmental scan must in all senses of the word be partial and personal. There is arguably a need to step back from the quotidian and to redefine what the library business is about; there is an accompanying need to develop a new theory and philosophy of digital librarianship. It may well be that traditional skills and principles remain relevant (albeit redefined), but it is no longer clear what business libraries are in and where they should now interface with other parts of the organizations they serve.

We have reached a point where entrenched and traditional organizational settings give rise to organizational clashes, as new issues and content emerge which do not fit historical patterns. The bundling of functions has imperceptibly changed, but we have become so busy and adept at keeping the library efficient and well managed that we have lacked the space to step back and observe it from a higher level. One perspective is that the library was created as a set of activities to minimize transaction costs. Now that all of these activities are possible for individuals and groups on the web, can we shift these transaction costs? Should we move on from that past to explore what categories of function are distinctive to libraries and librarians and which can be left to the web? Should the "vanilla" activity be outsourced or at least shared? Libraries have fallen into the trap of substituting means for ends and have not considered what is in the interest of their parent universities. It is, then, the purpose of this paper to review and scan the landscape facing university libraries and to attempt to identify the key competencies or core areas of work that the profession needs to grasp as its key to the future. 


\section{Influential Reports on University Libraries}

The UK's University Grants Committee Annual Report for 1921 (University Grants Committee, 1921) famously stated that "the character and efficiency of a university may be gauged by its treatment of its central organ - the library. We regard the fullest provision for library maintenance as the primary and most vital need in the equipment of a university." The seminal Parry Report (University Grants Committee, 1967) cited this statement with obvious approval, confirming that it remained as true as ever. And, indeed, universities in the UK and elsewhere continue to invest literally tens of millions of pounds in new library buildings without any substantial evidence that this is the best use of resources. Such buildings represent acts of faith rather than acts of evidence based policy. And yet there is a plethora of evidence, not all of it making comfortable reading.

This author's personal but certainly incomplete listing of such reports (del.icio.us, 2009) shows over three dozen reports prepared in the last few years by a variety of bodies. These come from a variety of commercial, educational and professional sources in the UK and abroad and range across the changing nature of users, the changing nature of content, the changing nature of scholarship and the changing nature of the world itself. Thus far, a significant proportion of these reports and studies has tended to be aimed at the library community and has not generated wider debate. But it is not sufficient for such analysis to be confined to the library community. As Campbell (2006) has commented:

Although these emerging, digital-age library services may be important, even critical, in the present era, there is no consensus on their significance to the future academic library - or even on whether they should remain as library functions carried out by librarians. In addition, at this point, the discussion of the future of the academic library has been limited to librarians and has not widened, as it should, to involve the larger academic community. Consequently, neither academic librarians nor others in the academy have a crisp notion of where exactly academic libraries fit in the emerging twenty-first-century information panoply...

Because of the fundamental role that academic libraries have played in the past century, it is tremendously difficult to imagine a college or university without a library. Considering the extraordinary pace with which knowledge is moving to the Web, it is equally difficult to imagine what an academic library will be and do in another decade. But that is precisely what every college and university should undertake to determine. Given the implications of the outcome, this is not an agenda that librarians can, or should, accomplish alone. (p. 30, emphasis added) 


\section{The Changing Nature of Users}

Prensky (2001a, 2001b) first coined the terms Digital Natives and Digital Immigrants, to describe those born before and those born after the internet was "invented" in 1993. Although this has proved a controversial division it has undoubtedly stimulated debate and is an extremely useful metaphor for describing the changing nature of users. There is an interesting parallel with the debate on climate change, which was initially heated and partisan but the steady and compelling growth in the body of evidence appears increasingly to have settled the debate. The same is true of digital natives. Perhaps most importantly, Prensky (2001a, 2001b) sees this division as signalling not simply incremental ratcheting up of technology and technological skills but as a fundamental discontinuity with the past:

Today's students - $K$ through college-represent the first generations to grow up with this new technology. They have spent their entire lives surrounded by and using computers, videogames, digital music players, video cams, cell phones, and all the other toys and tools of the digital age. Today's average college grads have spent less than 5,000 hours of their lives reading, but over 10,000 hours playing video games (not to mention 20,000 hours watching TV). Computer games, email, the Internet, cell phones and instant messaging are integral parts of their lives. (p. 4)

So what are the characteristics of these digital natives? Three recent reports tellingly demonstrate the rapidly changing nature of user abilities and expectations. The CIBER (2007) report discovered a number of traits which have a ring of familiarity to them. This report found that these researchers of the future:

- expect research to be easy and feel they can be independent in the process;

- do not seek help from librarians and only occasionally from professors or peers;

- when they cannot find what they need, give up and assume that the information cannot be found. Students often stop after their initial searches thinking they have completed the research process;

- have, through access to full text articles, seemed to have changed their cognitive behavior. Instead of having to read through material at the library, they can now download material at their desks. They do not feel the need to take notes or read through them to develop themes and ideas, an activity usually considered central to a focused research project;

- have failed to read through material, which is possible because electronic articles enable cutting and pasting. This, in turn, almost certainly leads to increased plagiarism - although the suspicion must be that this is done through ignorance more often than malice; and

- Use a model of collecting information of browsing and grazing. 
But perhaps the most depressing statistic for traditionalists is that these users spend four minutes on an e-article and only eight minutes on an e-book. Typical information seeking is "horizontal," that is to say skimming one or two pages then bouncing out. Indeed the dominant activity is not information gathering but navigation and finding their bearings. Information gathering is then squirreling, that is downloading, for later use (an interesting parallel can be drawn with filing cabinets full of unread photocopies!). Tellingly, the CIBER report discovers that digital natives are not information literate and that there is a huge gap of knowledge to be addressed.

A similarly depressing picture emerges from a recent OCLC (2006) study of user perceptions:

- $89 \%$ use search engines to begin a search;

- $2 \%$ use a library web site;

- $93 \%$ are satisfied or very satisfied with this;

- $84 \%$ are satisfied or very satisfied, if librarian assisted;

- Search engines fit the student life style;

- Library use is diminishing; and

- "books" are the library brand

It appears from this that the huge effort expended on creating library websites is largely nugatory. Even worse, when librarians assist users, satisfaction levels drop. One explanation for this is the "eat spinach" syndrome; that is, librarians try to show students what is good for them by instilling best practice, rather than conniving at the discovery of easy or quick shortcuts which achieve the objective in hand. Statistics on growing library entry figures may be used to offer a different message on library use, but such growth is often through the offering of additional non-traditional services such as wireless or network access. The library brand and image are then a point of interest. If one looks at sites built by librarians in Second Life, for example, they are full of trendy young avatars with raffish outfits, stylish hair, and not a skin blemish to be seen. That is how librarians want to be seen. But when users build libraries in Second Life, they create old fashioned oak shelved rooms full of leather bound tomes. Books are indeed the library brand.

Also worth noting is the annual Childwise Survey for 2008 (Childwise, 2009), part of a growing time series which reinforces the belief that fundamental change is happening. This report is particularly interesting since in Prensky's (2001a, 2001b) terms these are the first real natives of the post-Internet world.

- $40 \%$ of 9 -year olds have internet in their room

- They have six hours of screen time a day, with 1.7 hours online

- "2008 has seen a major boost in intensity"

- Reading for pleasure has declined from $84 \%$ to $74 \%$ in two years

- They are fluent communicators who don't read and rely on spellcheckers 
- They multitask

- They are abandoning print and paper and communicate in a completely different way

On a regular basis, commentators and press lament the growth of text messaging, the death of grammar and the inability of children to spell, and yet the message seems quite clear. Digital natives communicate in different ways.

\section{Digital Content}

Perhaps even more chilling, if less remarked, than Prensky's views on digital natives are his views on digital content:

It seems to me that after the digital "singularity" there are now two kinds of content: "Legacy" content (to borrow the computer term for old systems) and "Future" content. "Legacy" content includes reading, writing, arithmetic, logical thinking, understanding the writings and ideas of the past, etc - all of our "traditional" curriculum. It is of course still important, but it is from a different era.Some of it (such as logical thinking) will continue to be important, but some (perhaps like Euclidean geometry) will become less so, as did Latin and Greek. "Future" content is to a large extent, not surprisingly, digital and technological. But while it includes software, hardware, robotics, nanotechnology, genomics, etc. it also includes the ethics, politics, sociology, languages and other things that go with them. (Prensky, 2001a)

Perhaps the greatest failure of libraries in recent years has been to properly address the mushrooming growth of born digital content. Libraries response to e-content has been two-fold. First, we have focused on commercially available material, especially journals. Huge and arguably disproportionate amounts of time and energy have been devoted to licensing and consortial deals which are not basically different from the ones publishers offer to consortia in other countries. Second, we have digitized quantities of the paper collections we already own. Now this, undoubtedly, makes the collections more widely available, and allows us to understand and develop relevant technologies, but fundamentally, we have created "cabinets of curiosities" (Milne, 2008). All too rarely, a substantial effort has been made to aggregate material and add value, with the Valley of the Shadow (University of Virginia, 2007) and the Emory University (2008) TransAtlantic Slave Trade Database projects being perhaps the best examplesexamples worth emulating. In the UK a number of more recent initiatives, ranging from the deposit of e-theses to creating a research data store, have targeted specific issues at national level, but these are, to a degree, piecemeal responses to specific issues rather than part of an underpinning philosophy. 


\section{Can University Libraries be Replaced?}

One of the traditional strengths of libraries has been the depth and scale of their collections. This strength was emphasised in the early days of automation when the combination of IFLA's UBC (Universal Bibliographic Control) and UAP (Universal Availability of Publications) meant that scholars gained ready access to those collections outside the institutional walls. But, "when the broad digital availability of books erodes the comparative advantage of large research collections, where will the library's comparative advantage lie?" (CLIR, 2008, p. 4). Or, to put it another way, when there are thirty five million volumes on Google Books, why does an institution need a library? It is very easy to construct a table which demonstrates that every significant library activity or process has been usurped by one or more social networking tools. Each of the arks of the professional covenant has alternatives which are readily available to users at times and in places which are convenient to them, as seen in Table 1.

TABLE 1 The pessimists view of libraries and their future

\section{Traditional Library}

\section{Activity}

Cataloguing

Classification

Acquisitions

Reference

Preservation

User instruction

Working space

Collections

Professional judgement

\section{Web 2.0 World}

Automated metadata, del.icio.us

Folksonomies and the semantic web

e-bay, Paypal, Amazon and Abebooks

Yahoo Answers and Wikipedia

Digital Archives and repositories

Chatrooms

Bedroom and Starbucks with a laptop

Youtube, Flickr, Institutional Repositories,

Open Access

The wisdom of crowds

More positively, it is possible to extend this table to show ways in which libraries and librarians can use the same or other tools to offer relevant services and collections in the social networking environment as can be seen in Table 2.

TABLE 2 The positive potential use of social networking tools by libraries

\begin{tabular}{|c|c|c|}
\hline $\begin{array}{l}\text { Traditional } \\
\text { Library }\end{array}$ & Web 2.0 World & Library 2.0 World \\
\hline Cataloguing & $\begin{array}{c}\text { Automated metadata, } \\
\text { del.icio.us }\end{array}$ & Metadata \\
\hline Classification & $\begin{array}{l}\text { Folksonomies and the } \\
\text { semantic web }\end{array}$ & $\begin{array}{l}\text { Locally provided and } \\
\text { relevant folksonomy }\end{array}$ \\
\hline Acquisitions & $\begin{array}{c}\text { e-bay, Paypal, Amazon and } \\
\text { Abebooks }\end{array}$ & $\begin{array}{l}\text { E-archives, e-data trust } \\
\text { metrics and quality }\end{array}$ \\
\hline
\end{tabular}




\section{TABLE 2 The positive potential use of social networking tools by libraries}

$\begin{array}{lcr}\begin{array}{l}\text { Traditional } \\ \text { Library }\end{array} & \text { Web 2.0 World } & \text { Library 2.0 World } \\ \text { Reference } & \text { Yahoo Answers and } & \text { Wikipedia } \\ \text { Preservation } & \begin{array}{c}\text { Digital Archives and } \\ \text { repositories } \\ \text { Chatrooms }\end{array} & \begin{array}{r}\text { Institutional repository } \\ \text { User instruction }\end{array} \\ \text { Working space } & \begin{array}{c}\text { Bedroom and Starbucks with } \\ \text { a laptop }\end{array} & \begin{array}{r}\text { Moderated chatroom } \\ \text { Wired campus and 24-hour }\end{array} \\ \text { Collections } & \begin{array}{c}\text { Youtube, Flickr, Institutional } \\ \text { Repositories, Open Access }\end{array} & \begin{array}{r}\text { Aggregation of unique } \\ \text { Professional }\end{array} \\ \text { judgement } & \text { The wisdom of crowds } & \text { Teaching retrieval skills }\end{array}$

Three of these uses, in particular, may be seen as the core on which a digital library philosophy could be built: trust metrics, the teaching of information retrieval skills, and the aggregation of unique content.

\section{Trust Metrics}

Geoffrey Bilder (2006) has noted that "every day, Internet users are pelted with spam, hoaxes, urban legends, and scams -in other words, untrustworthy data. The Internet is largely without any infrastructure to help users identify authoritative and trustworthy content. Indeed, the history of the Internet is littered with examples of how technologists have underestimated the crucial role that social trust and authority play in communication." In a print world we have a set of reference points which allow us to define trusted brands. If we give a book to a legal deposit library, we have a view that this ensures longevity; if a book is published by a major university press, we again will have a view on the likely authority of the author, on the quality of the research; if a book is held in the university library we will have a view on its likely relevance, and so on. Although we have not exploited the fact, libraries too are a trusted brand, seen as neutral, impartial, disinterested, and helpful. On the Internet a few brands are beginning to emerge as trusted, such as Google. It will be interesting to see whether this lasts. But trust in Google has already been harmed by its apparent kowtowing to Chinese government demands to ban access to websites and by the discovery that it makes information on usage available to US security services, irrespective of the country of the user (Globe and Mail, 2008). US librarians on the other hand are very publicly rebelling against the demands of the Patriot Act to make client information available to these self-same security services, risking jail in the process (Raw Story, 2006).

So, although it is perhaps not clear yet how we best take advantage of this status as a trusted brand, it is an area to be exploited. Perhaps in areas such 
as social networking for research, it should be libraries that create and manage the frameworks which researchers populate with content.

\section{The Teaching of Information Retrieval Skills}

There has been a recognition in recent years that information literacy is a basic need which should feature in any students portfolio of transferable skills. Indeed, the previously mentioned CIBER report (2007) reflects a growing view that such skills should be taught very early at school and not university. However there is a real need for universities to work on what might better be defined as information fluency. Unsurprisingly, publishers sell on difference not similarity. Every dataset, every aggregating product, every software publisher has a different system. Users need to learn how to maximize the outcomes of using or searching such products not just in practice but in terms of principles; they need to understand how to assess the quality and authority of information sources. There is a plethora of products with inadequate help and support. User instruction then returns to being a central responsibility for library staff. Ownership of this area is perhaps not very contentious, and it is not dwelt on at length here - but it should be seen as a central plank in defining the future role of the library. If the most basic of all professional skills is the organization of knowledge, the optimal retrieval of knowledge should be a close second. SCONUL's Advisory Committee on Information Literacy (SCONUL 1999, 2004) in particular has done very significant work in this field, which this superficial account can only acknowledge as critically important.

\section{Born Digital Content and its Aggregation}

IDC (Gantz, 2008) has calculated that by 2011, the digital universe will be ten times the size it was in 2006. To deal with this explosion of born digital content in size and complexity, it suggests that information organizations must address three key imperatives.

First, they will need to transform their existing relationships with the business units of the organization, in our case departments and faculties. It will take all competent staff in an organization to deal with information creation, storage, management, security, curation, retention, and disposal in an enterprise. Dealing with this digital universe is not a technical problem alone, nor one for a single department.

Second, they will need to spearhead and champion the development of organization wide policies for information governance: information security, information retention, bibliographic integrity, data access, data mining, standards, data asset management, archiving, and compliance. It seems inherently improbable that the model of a single centralized store of all born digital material will be seen as either acceptable or desirable to academic and administrative colleagues. However, reasserting our primacy and expertise in how to organize knowledge and offering authoritative advice on these issues promises a viable and challenging role. 
Third, they will need to promote new tools and standards for the organization, from storage optimization, unstructured data search, and database analytics to resource pooling (aggregation) and management and security tools. All will be required to make the information infrastructure as flexible, adaptable, interoperable, and scalable as possible. Many of the tools are already in place-from the Web 2.0 social networking technologies and the terabyte drives in our IT departments to unstructured data search software and the Semantic Web - to manage the digital universe. Addressed properly, we can turn information growth into productive corporate growth.

Although there may be the odd exception (and the growth of mandated institutional repositories will increase those), there can scarcely be a university in the UK which could provide a comprehensive annual list of published staff outputs. A vanishingly smaller number would be able to describe, never mind quantify the nature, number, and even location of outputs created each year by staff. The following list is a large but probably not comprehensive one of the outputs a typical university might create and store. It seems quite improbable that any university has in place policies for archival selection, curation, and digital asset management of these types of material although there will undoubtedly be individuals or groups looking after parts of the whole.

- Research papers

- Conference presentations

- Theses

- Wikis

- Blogs

- Websites

- Podcasts

- Reusable Learning Objects

- Research data

- E-Lab books
- Streamed lectures

- Images

- Audio files

- Digitized collections

- E-Archives

- E-mail

- HR Records

- Student/Staff records

- Corporate publications

- National heritage artefacts

One glaring gap remains, the absence of any acceptable definition of trusted repositories. We understand this concept for printed works and have set up legal deposit libraries and major research libraries with sets of standards and values which are based on trust. Until very recently, computing longevity was based on months rather than the centuries to which libraries aspire. Although much work has been undertaken on the technical issues of extending the life of computer objects, the concept of trust has lacked substance. Interestingly, if one turns back to the sort of trust principles which are embodied, for example, in the Maori oral tradition, one can find a set of broad principles which perfectly encapsulate what is required. The five Maori tests (Winiata, 2002) are to:

- Receive the information with accuracy;

- Store the information with integrity beyond doubt;

- Retrieve the information without amendment;

- Apply appropriate judgement in the use of the information; and

- Pass the information on appropriately. 
If libraries could deliver these five Maori tests, they would offer a huge benefit to organizations beginning to grapple with issues of digital information ownership. The Computing Centre may still manage the technology which holds the data, but the library can still have responsibility for the content.

It would, of course, be naive in the extreme to assume that universities and the large vested interests they contain will simply, uniformly and willingly, hand over their digital assets to the Library. We must assume that we live in a world of distributed content. However, it does not seem implausible to suggest that the library could aspire to be the point of authority and advice for the university on the standards which should be adopted for everything from copyright to data curation, ensuring that the university adopts and promulgates standards which meet nationally accepted best practice and perhaps even policing their implementation.

Almost as important as gaining control of such born digital material is adding value to it. Not only must it be bibliographically sound and therefore accessible, it will ideally be aggregated with material from other organizations. A recent ARL report (Lowry, 2009) identifies several potential threats to libraries of which two seem key:

- Outsourcing of dissemination activities and a growing role for content industries in setting policies and defining services could further erode research institutions' control of the intellectual assets produced by research and teaching; and

- If libraries turn inward and focus on protecting local resources, they could pull back from essential cooperative work

Libraries have an enviable track record of working together and the interlending system, based on IFLA's twin programs of Universal Bibliographic Control and Universal Availability of Publications are triumphs of international diplomacy. A new, similar effort is required to ensure that the born digital material created by our institutions is available coherently and effectively and that it is not simply left to the content industries to cherrypick items which they perceive to have commercial worth.

\section{Conclusion}

It is then possible in the light of this environment scan to highlight the agenda to be prosecuted by libraries and librarians. Of course, there is no universal panacea and the emphases will vary from institution to institution, but it seems certain that these concerns will be at the core of any redefinition of the Library's role: 
- Building e-Research collections and contributing to a virtual research environment of born digital material both nationally and internationally;

- Importance of kite marking, quality assurance, trust metrics, and relevance ranking;

- Managing institutional born digital assets, ensuring their bibliographic integrity and making value added content available;

- Training/Information fluency/information literacy; and

- Policy and standards advice to institutions

Persuading not just librarians but institutions that this is an agenda to be tackled and resolved will indeed ensure a bright dawning for the libraries of the future.

\section{References}

Bilder, G. W. (2006) In Google We Trust? Journal of Electronic

Publishing Vol. 9.1 - Web. 1 May 2009.

< $\underline{\text { http://hdl.handle.net/2027/spo.3336451.0009.101> }}$

Campbell, J. (2006) Changing a Cultural Icon: The Academic Library as a Virtual Destination.. EDUCAUSE Review Vol. 41.1, pp. 16-31. Print

Childwise (2009) — Web. 1 May 2009.

$<$ http://www.guardian.co.uk/media/2009/jan/19/internet-generationparents $>$ "ChildWise Monitor Trends Report 2008 Norwich: Childwise, 2008" as described in The Guardian for 19th January 2009.

CIBER (2007) Information Behaviour of the Researcher of the Future CIBER, London — Web. 1 May 2009.

$<$ http://www.bl.uk/news/pdf/googlegen.pdf $>$

CLIR (2008) No Brief Candle: reconceiving research libraries for the

21st Century Council on Library and Information Resources,

Washington - Print

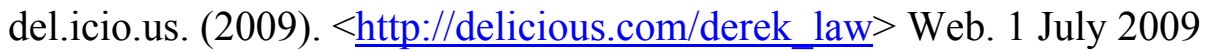

Emory University (2008) The Trans-Atlantic Slave Trade Database

Project - Web. 1 July 2009. < http://metascholar.org/TASTD-

Voyages/>

Gantz, J. F. (2008) The diverse and expanding digital universe: An Updated Forecast of Worldwide Information Growth Through 2011 IDC, Framingham, MA — Web. 1 May 2009.

$<$ http://www.emc.com/collateral/analyst-reports/diverse-explodingdigital-universe.pdf $>$ 
Globe and Mail (2008) For a recent Canadian example see

$<$ http://www.theglobeandmail.com/servlet/story/RTGAM.20080324.wrg oogle24/BNStory/incubator> — Web 1 May 2009.

Lowry, C. (2009) Transformational Times: An Environmental Scan Prepared for the ARL Strategic Plan Review Task Force Association of Research Libraries, Washington, DC — Print

Milne, R. (2008) A description coined by Ronald Milne of the British Library — Personal communication, 19 June 2008

OCLC (2006) College Students' Perceptions of Libraries and Information Resources: A Report to the OCLC Membership OCLC , Dublin, $\mathrm{OH}$ - Print

Prensky, M. (2001a) Digital Natives, Digital Immigrants.. On the Horizon V9.5, pp. 1-6. — Print

Prensky, M. (2001b) Digital Natives, Digital Immigrants Part 2: Do they really think differently? On the Horizon V9.6, pp. 1-6. - Print

Raw Story (2006) One case is described at

$<$ http://www.rawstory.com/news/2006/Gagged_librarians_break_silence on_Patriot_0531.html> - Web. 1 July 2009.

SCONUL (1999) Information skills in higher education. Briefing Paper SCONUL, London - Web 1 May 2009.

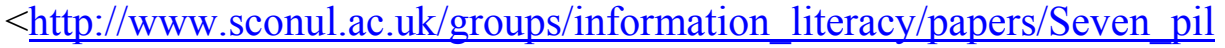
lars2.pdf $>$

SCONUL (2004) Learning Outcomes and information literacy

SCONUL, London — Web. 1 May 2009.

$<$ http://www.sconul.ac.uk/groups/information_literacy/papers/outcomes. pdf $>$

University Grants Committee (1967) Report of the Committee on Libraries [The Parry Report] HMSO, London - Print

University Grants Committee (1921) Report, 3 February. (Cmd. 1163)

HMSO, London - Print

University of Virginia (2007) Valley of the Shadow - Web. 1 July 2009 $<$ http://valley.vcdh.virginia.edu/>

Winiata, Whatarangi (2002) Repositories of Röpü Tuku Iho: A Contribution to the Survival of Mäori as a People. Keynote address, LIANZA Conference Wellington - Web. 1 May 2009 $<$ http://www.lianza.org.nz/library/files/store 019/WhatarangiWiniata.pd $\underline{f}>$ 